\title{
Modeling of Innovative Teaching in an Austrian Primary School
}

\author{
Eliza Avdiu \\ University "Isa Boletini" in Mitrovica, \\ Ukshin Kovaçica Mitrovice XK, 40ooo, Kosovo \\ Andrea Holzinger \\ Head of Institute for Early Childhood and Primary Teacher Education, \\ University College of Teacher Education Styria, \\ Hasnerpl. 12, 8010 Graz, Austria
}

\section{DOI: https://doi.org/10.36941/jesr-2022-0044}

\section{Abstract}

The purpose of this research is to understand the integration of innovative teaching and its modeling through teachers' experiences as one of the most advanced approaches to teaching today. Eight teachers of a primary school in Austria were involved in this study. Qualitative methods, with semi-structured interviews, were used in this study. In this study, semi-structured interviews, classroom observations and participation were conducted, during a one-month period. The results of this study illustrate innovative teaching experiences through new models, which have begun to be implemented this year in this school, such as: digital and social competence as a new field, teaching in the studio, combining mathematics with music, learning drama with technology and other subjects, learning in the school's green kindergarten, learning with digital tools, and a series of play-modeled activities which focused on active student participation. Through these models, students learn how to organize the learning process themselves, to choose what will work in accordance with their interests, in order to increase students' independence in their work and their preparation for the living environment where they grow up.

Keywords: innovative teaching, students, primary education, teachers

\section{Introduction}

The purpose of this research is to provide innovative teaching models to create richer and more rewarding experiences for teachers and students. Today's educational perspectives aim to better realize the purpose of learning by increasing the effectiveness of classroom's activity and encouraging extracurricular learning.

Innovation is a phenomenon that carries in itself the essence, methods, techniques, technologies, and content of the new (Mynbayeva et al. 2017). The application of innovative teaching and learning methods is critical if we are to motivate and engender a spirit of learning as well as enthusiasm on the part of students (Subramani \& Iyappan, 2018). Pedagogy of the twentieth century differs from the pedagogy of the twenty-first century (Mynbayeva et al. 2017). 
However, change in schools is complex and chaotic it "will always fail until we find some way of developing infrastructures and processes that engage teachers in developing new understanding, deep meaning about new approach of teaching and learning” (Fullan, 2001, p.37). The biggest challenge for any teacher is to make each student to be attentive in the class, and transmit ideas effectively enough to create a lasting impression (Vijayalakshmi, 2019). Allowing students to play with the tools could enhance pupils' motivation to think, understand and learn in innovative ways (Cachia et al. 2010). Educationists around the globe are advocating for innovating and improving the existing learning methods, and also for experimenting with new teaching styles (Puranik, 2020). Therefore, innovative teaching is the process leading to creative learning, the implementation of new methods, tools and contents which could benefit learners and their creative potential (Cachia et al. 2010). Any teaching method without destroying the objective could be considered as innovative methods of teaching (Subramani \& Iyappan, 2018). These searchers believe that the core objective of teaching is passing on the information or knowledge to the minds of the students. Innovative schools adopt an idea and strategically implement it into the schools' organizational processes, which may include the schools' philosophy, curriculum, culture, climate, and structure (Pollock, 2008). Innovative teaching and learning methodologies such as short lecture, simulation, role-playing, portfolio development and problem-based learning (PBL) are very useful in addressing the rapid technological advances and developing workplaces that will be required in the foreseeable future (Subramani \& Iyappan, 2018).

Modern pedagogical paradigms and trends in education, reinforced by the use of Information and Communication Technology (ICT), create prerequisites for use of new approaches and techniques in order to implement active learning (Vijayalakshmi, 2019). The greater the strategies and methods of teaching the teacher has, the more interesting, diverse it conducts classes, better motivates the student's cognitive activity, shapes the experience of solving nonstandard problems, promotes in-depth training and the steady assimilation of technology of practical activity (Mynbayeva et al. 2017).

The active use of innovative teaching methods by teachers is a necessity nowadays. In Austria, particularly innovative schools have already started to implement the model during the school year 2017/18 (Karl, 2017). According to this study, experience is passed on to all other schools in the form of best practice examples and transfer of know-how and gradual implementation of digital basic education in primary and lower secondary education starts with a pilot at innovative schools of the eEducation network. Innovative teaching approaches are usually introduced in the context of a new curriculum, a teacher education and professional development program, or a combination of the two (Maass et al. 2019).

This article presents experiences and reflections on modeling innovative teaching in an Austrian primary school.

The research question was: "What are the practices of teachers in modeling innovative teaching in primary education".

The preparation of questions for the teachers' interview is based on previous researches, such as: Do teachers use innovative teaching methods? What are the advantages of innovative teaching methods? Why do teachers use innovative teaching methods? Have teachers learnt how to use innovative teaching methods: trainings, courses, etc.? (Mynbayeva et al. 2017) What does the innovative and creative teaching mean according to you? What do you think are the most important aspects of your teaching? (Serdar, 2015).

These categories were further divided into other subcategories, which were modified later, after a pilot interview. Teachers were asked the following questions:

1. What are teachers' views on innovative teaching?

2. What are the innovative models that are being applied in your class?

3. Illustrate, through examples, the innovative teaching models.

4. What is the importance of innovative teaching for the students' learning?

5. According to your experience, has innovative learning proven to be successful for your student? 


\section{Research Methods}

\section{$2.1 \quad$ Research Model}

Qualitative methods were used in this research. Semi-structured interviews and classroom observations were conducted as well. As stipulated by the descriptive research, we interpret other data sources, such as observation notes and conversations with teachers (Johnson \& Christensen, 2017). The aim was to hear the teachers' "voice" about innovative teaching through their stories of experience and the "language of practice" (Gudmundsdottir, 2001; pp. 228-229).

\subsection{Participants}

The sample in this study is represented by eight teachers of four classes of a primary school. The maximum variation sampling was used for the selection of teachers (Yıldırım \& Şimşek, 2006). The criterion set out in this study was the training of teachers on the use innovative teaching. Three of the interviewed teachers had six years of experience, one had fifteen years of experience, two had seven years of experience, and two had five years of experience. Two of the classes included in the research were multigrade classes (1-4), a second grade and a fourth grade of primary education.

\subsection{Data collection}

The study was conducted in a one-month period (January, 2020) during a study visit to the University College of Teacher Education Styria (PHSt). The Training Primary School of the University College of Teacher Education was also in the campus of this University College, which served as a practical primary school for new teaching students. Therefore, a University College expert / teacher contacted primary school education teachers and asked them to participate in the interview.

Interviewees' replies were interpreted using descriptive analysis and, in some cases, they were even interpreted verbatim. The classrooms where the interviews took place were monitored during this month and this helped us to understand more closely the other aspects such as the classroom environment, extracurricular activities, student vacations and many other aspects, which were implemented in the school this year and it helped us understand teachers' practices and link them to their answers.

\subsection{Data analysis}

Interviews were recorded with digital recorders and then they were analyzed. Teachers' names were recorded and then coded. The duration of interviews ranged from $20-25 \mathrm{~min}$. Teachers were interviewed in the last week of the month.

We started by reading teachers' narratives, in which teachers described their various teaching practices and principles, often illustrating them with teaching situations from their own classes (Riessman, 2008).

The formula (i.e., Reliability $=$ Agreement $/$ Agreement + Disagreement x 100) formed by Miles and Huberman (1994), was used to estimate the inter-coder reliability rate. According to these studies, in qualitative data analyses, the inter-coder agreement rate is expected to be above $90 \%$ and, for this study, it was calculated as $95 \%$. Since the criterion of this study was the training of teachers on the innovative approach, we understood from the teachers that, during the last two years, they had attended trainings focused on integrated teaching, such as: combining mathematics with music, trainings where children can choose what to learn, digital and social competences, pedagogical reforms, advanced training for children with special needs, etc. They also said that there were many subjects in master studies (six of them had completed their master studies), where the innovative approach to learning was integrated. 
We present below the data that emerged from teachers' interviews, illustrated with examples in the modeling of innovative teaching.

\section{Results}

The following section presents the results that emerged from teachers' interviews, illustrated with examples from their experiences. The answers provided during the interviews are listed separately in the table for each question.

Table 1: Teachers' views on innovative teaching

\begin{tabular}{|l|l|}
\hline \multirow{5}{*}{ Teachers trained in innovative teaching } & $\begin{array}{l}\text { acquisition of changes that occur through the digital platform, } \\
\text { new way of thinking, } \\
\text { students' ability to choose methods, } \\
\text { active participation of students in learning, } \\
\text { learning in the interest of students, } \\
\text { practical lessons, } \\
\text { adapting new things to school, } \\
\text { game lessons, } \\
\text { project learning, } \\
\text { students learn on their own, }\end{array}$ \\
\hline
\end{tabular}

According to teacher H. P., the innovative learning means active participation of the students e.g. students can choose to do what they want by exploring new things and acquiring knowledge through the digital platform. Today, children are very skilled in using the digital platform and when they have an idea to do something, but they don't know how to do it, this approach enables them to research for it, to find arguments for the new and most appropriate way and it prepares them for the challenges of the life. Whereas according to the views of teacher A.S, the innovative approach to learning compared to the learning of the last century provides students with the opportunity to choose methods, to learn through play and to make decisions. Teachers think that while teaching is constantly changing and shifting from teacher-centered teaching to student-centered teaching, the innovative learning brings a new approach to the learning context.

Table 2: What are the innovative models that are being applied in your class?

\begin{tabular}{|l|l} 
Teachers trained in innovative teaching & $\begin{array}{l}\text { learning in workshops } \\
\text { digital platform } \\
\text { individualized daily plan for each student } \\
\text { extension of school hours } \\
\text { green school garden, }\end{array}$ \\
\hline
\end{tabular}

Concerning this question, teachers showed that they have adopted some new methods in the school this year, such as teaching in the studio in mixed classes from 1-4 grade and in other classes where children study together in groups. Teaching in workshops is held twice a week, mainly by organizing four different workshops in language subjects and four different workshops in mathematics subjects, and in other subjects as well. There are practical lessons, e.g. experiments, table exercises, games with digital tools, logical mathematical games, etc., which are related to various curricular subjects and which are used in these workshops. The students have to create these lessons through drama, music, choreography, sports, or arts and children decide what to choose. Teacher T.A told us that the children in the studio learn two topics according to the plan they have, but the important thing is that they have to learn on their own. Students are making plans on what they will learn in language and what they will practice in math and they also learn how to organize themselves, so they have to 
choose the things they need and the things they want to do. K.O also said that choosing the methods by the students is also an opportunity for them because they see in which areas they need more knowledge e.g. one of my students said: "Oh, oh, I'm not good at grammar" and, according to this, we can practice grammar or math, as well, and that's pretty innovative. Here the children practice on their own. They have to find a way to master the tasks and then plan and inform us when they want to take the test. As the teacher P.L shows, one child says: "I will be ready to take the test in March", while the other can say that he can take the test in two weeks. Because of this, we have to make individual plans for each student.

Teachers also showed that they apply the new model of school time duration, which means that classes start at 07:30 and end at 16:00. This means that students are spending a long time in the school and many developments and advances can happen during this time. During this time, students have two one-hour breaks. Another innovation in this model is that during leisure time, students are supervised by two assistant teachers in the class. These assistant teachers are not involved in the teaching process. They take care of students and follow them during the meal time, during the break in the garden and outside the learning environment. They are asking students about their ambitions, hobbies and similar things and then report this to the teachers involved in the teaching process. They are trying to integrate this information into each student's individual plan in order to have more knowledge and information about students. During the school time, the school also implements the so-called "green kindergarten of the school" where children go out every day and have fun or implement projects and various activities that are planned within the curriculum.

Table 3: Teacher practice in modeling innovative learning illustrated with examples

\begin{tabular}{|l|l|}
\hline \multirow{2}{*}{ Teachers trained in innovative teaching } & $\begin{array}{l}\text { the combination of music with mathematics, } \\
\text { learning drama with technology, } \\
\text { outdoor learning, } \\
\text { domino activities, memory games, problem solving, } \\
\text { digital learning for children with learning difficulties, } \\
\text { learning to manage work, }\end{array}$ \\
\hline
\end{tabular}

According to teachers' data, the combination of the subject of mathematics with music is also one of the innovative approaches, which has been implemented in this school. According to T.A, the development of the subject of mathematics is associated with musical sounds because mathematics, as a science, is more complex and not all the children love it. When this subject is associated with music, it makes the students feel more relaxed. Teacher B.N said that, depending on the topic that is learned in mathematics, they try to relate some parts with arts, e.g. illustrations with potatoes, so students can draw around potatoes, sing about potatoes etc.

Another experience is shown by teacher P.N who teaches the first grade. He has developed an activity where students take their tablets (as they all have basic knowledge) and are left free to move throughout the school hallway and search codes that were previously placed in different places on the walls. Students should find these codes, photograph them, print them, and insert the codes in their IPads. Using the links provided with the codes, students can discuss different topics, games, and information. The teacher A.S is using another method, "learning in the green kindergarten". He tells his students when they can go to the school kindergarten, where students take their IPads along and take pictures in the kindergarten surrounding. Then, students hang pictures of the last spring season. After that, students compare the pictures and discuss where they see grass growing, changing colors, changes in people's clothing, etc.

Another model of teaching is used by the teacher H.P. She uses digital technologies to communicate with a girl with special needs and through her gestures, intonation and speaking, the teacher can understand if the student feels tired or angry, if the student needs help or is hungry. Drama and technology also play an important role in modeling innovative teaching. P.L said that he 
uses a bit of drama and a bit of technology in the curriculum, and shows the students the basic roles they have in the class so that they can move through them, and every child tries and seeks new things. This is very attractive for the children, because they show considerable interest.

Teachers prefer to prepare the schedule at the beginning of the week, together with the students. In this way, students know when they will have math or other subjects, when they can go out into the kindergarten, and when they will have lunch break. In this way, the children know what will happen during the day and at the same time, they will learn to manage their time and tasks.

Table 4: The importance of innovative teaching for students' learning

\begin{tabular}{|l|l|}
\hline \multirow{5}{*}{ Teachers trained in innovative teaching } & $\begin{array}{l}\text { attractive to students } \\
\text { facilitate and strengthen student-student relations, learn new } \\
\text { concepts, new ways, convey knowledge about life, innovation in } \\
\text { their work, acquire life skills, } \\
\text { increase independence, think on their own way, balance } \\
\text { between student-centered teaching and center-based teaching }\end{array}$ \\
\hline
\end{tabular}

According to teacher P.L, innovative learning is a good opportunity to make a balance between center-based teaching and student-centered teaching because students learn by doing. Today, teachers can transmit any concept in an innovative way and, with a few changes and modifications, they place the information in the center of learning. The importance of innovative approach with digital tools was also shown by the teacher B.N who said that these new means of communication enable and facilitate relationships with students (especially with children with special needs) because it is often impossible to communicate with these children when they are not in a good mood or cannot express themselves well, so this technology helps teachers understand what children need and how they feel.

During our observations in the classroom, we have seen how creative children are and how they work with very attractive methods, especially when they learn new things during the lesson.

Table 5: In your experience, has innovative learning been successful for your students?

\begin{tabular}{|l|l|}
\hline Teachers trained in innovative teaching & $\begin{array}{l}\text { greater desire for school open-minded student, } \\
\text { gain independence, } \\
\text { convey knowledge even in extracurricular situations, } \\
\text { by following their own way of learning, they learn to manage } \\
\text { themselves }\end{array}$ \\
\hline
\end{tabular}

Teachers said that the integration of social competence and digital platform as a new field has made the learning process more diverse and faster for both the children and the teachers. Teacher P.L says it is a pleasure to see that your students are interested in learning new things e.g. when they work in the computer room, practice math on IPad or when they learn in the workshop. However, teachers said that innovative teaching is sometimes a difficult process because it requires individual planning of students to adapt to their skills and needs, e.g. one student works on one page of the book while the other one works on the other page of the book; thus, they should find the right way so that the children will accept them well.

\section{Conclusions and Discussions}

In general, teachers see innovative teaching as open teaching oriented towards the acquisition of new things through the use of digital platforms, which helps children to be in step with the developments that are taking place and to increase their readiness for the life that awaits them. However, they emphasized as innovative any active participation of students in other forms that they do in the 
classroom, such as learning through play, drama, learning outside the school environment as an opportunity to involve students' interests and develop different skills. Any teaching methods that serve this purpose without destroying the objective could be considered as innovative methods of teaching (Subramani \& Iyappan, 2018).

This study also identified some innovative models that have been adopted recently in this school. One of these innovative models is teaching in workshops, which is mainly held twice a week in different subjects. The most important aspect of these workshops is that students choose what to practice, which things they need most, they choose the methods to organize themselves and decide when they will take the test. Also, the extension of the school time from 07:30 - 16:00, enables students to integrate different things, to practice and reinforce, and to have fun as well. The supervision by teaching assistants in students' vacation schedules is also very important in this model in order to identify the characteristics of students, to know as many students as possible and to take these characteristics into account in the student's files i.e. in the students' personal plans prepared by their teachers. Teachers said that digital education is the highest level of education today and it surprises them every day more and more that children are in the era of digital education and have the potential to use digital technologies. So, digital competencies should be developed as much as possible in school by the application of various digital games and gaming activities as well, because this is the modern world and the school should offer it.

Teachers showed different models for the integration of innovative learning from their practice. The teaching integrated with the digital platform was specially emphasized, especially the teaching of mathematics with music illustrated with practical examples. Even during our observations in the classroom, we noticed in every hour of mathematics a light musical instrument which accompanied the whole hour, but also the activities of learning mathematics were integrated with drama, music, art, natural sciences, etc. Learning in the green garden was another part of the innovation through the integration of different subjects, which was shown by the teachers as an attempt to prepare children for the living environment where they will grow up and the changes that are taking place through the use of digital tools. Teachers also said that when they combine drama and technology they always try to do something different with the students. They explore and incorporate new things, then take on roles and these are quite attractive to the students.

During our classroom observation, we also observed activities with students focused on the development of planning and management skills. Today, children are much more creative and interested in their work, and even when they work on their IPads in the classroom, we see that one works with one plan and the other works with something else and teachers have to fulfill the first plan first and then move to the other plan and we see that this is being accomplished because they are interacting with new things. In a study conducted in Kazakhstan, which involved 66 teachers, the introduction of innovative teaching methods was found to be actively developed (Mynbayeva et al. 2017).

According to teachers, the importance of modeling innovative teaching lies mainly in increasing students' independence in their work, in incorporating new concepts by discovering the way that corresponds to their learning. This is exactly what the school should enable today. Based on a study, it turned out that innovative projects can advance students in learning and provide self-learning opportunities (Yuen, 2004).

Considering that nowadays innovative approaches can help students in many ways to be up to date with the new developments, new means of communication in this study have shown progress in facilitating relationships between students and in increasing their interest in learning. According to a research, the main purpose of applying innovative teaching was to increase students' interest in learning, which resulted in $92.42 \%$ (Mynbayeva et al. 2017).

On the other hand, innovative teaching is also a challenge for teachers, considering the process of changes that are taking place to implement the new curriculum in order to cover the digital competence which has been lacking as a field, but it is showing progressive results given that teachers stay all day long in school and this enables the learning process to become faster, more improved and 
more diverse. Today, the modeling of innovative teaching requires the updating of the material, because the approaches to methods that bring information to the learners to meet their needs and prepare them for the future are changing just as life is changing.

\section{References}

Cachia,R., Ferrari,A., Ala-Mutka,K., \& Ppunie,Y.(2010).Creative Learning and Innovative Teaching Final Report on the Study on Creativity and Innovation in Education in the EU Member States. JRC Scientific and Technical Reports. From: http://www.eurosfaire.prd.fr/7pc/doc/1300702480_jrc62370_learning_teaching_2010.pdf

Fullan, M. (2001). The New Meaning of Educational Change, 3rd Ed., New York: Teachers College, Columbia University.

Gudmundsdottir, S. (2001). Narrative research in school practice, In V. Richardson (Ed), Handbook of research in teaching (pp.226-240). 4thed.Washington, D. C:American Educational Association.

Johnson, B., \& Christensen, L. (2017). Educational Research Quantitative, Qualitative, and Mixed Approaches (6th ed.). Thousand Oaks, CA: Sage.

Karl, L. (2017). Country Report on ICT in Education. Austria. Europian Schoolnet. From: http://www.eun.org/documents/411753/839549/Country+Report+Austria+2017.pdf/a86bf21c-6f9o-4753-a3c1$\mathrm{fd} 715 \mathrm{fe} 49 \mathrm{ceo}$

Maass, K., Cobb, P., Krainer, K \& Potari, D. (2019). Different ways to implement innovative teaching approaches at scale. Educational Studies in Mathematics, volume 102, pages303-318. Springer

Miles, M. B., \& Huberman, A. M. (1994). Qualitative Data Analysis: An Expanded Sourcebook. Thousand Oaks, CA: Sage Publications.

Mynbayeva, A., Sadvakassova, Z., Akshalova, B. (2017). Pedagogy of the Twenty-First Century: Innovative Teaching Methods. From: https://www.intechopen.com/chapters/5806o

Pollock, K. (2008). The Four Pillars of Innovation: An Elementary School Perspective. The Innovation Journal: The Public Sector Innovation Journal, Volume 13(2). From http://innovation.cc/peer-reviewed/pollack_innovative2.pdf

Puranik, Sh. (2020). Innovative teaching methods in higher education. BSSS Journal of Education ISSN 2320-1258, vol.IX, Issue-I. From: https://bssspublications.com/PublishedPaper/Publish_245.pdf

Riessman, K. C. (2008). Narrative Methods for the Human Sciences. CA, ISBN: 978-0-7619-2998-7. USA: SAGE Publication

Serdar, A. R. (2015). Searching for Innovation, Creativity and 21st Century Skills: A Case Study of a Suburban Elementary School District. National College of Education. From: https://digitalcommons.nl.edu/cgi/viewco ntent.cgi?article $=1128 \&$ context $=$ diss

Subramani, P., \& Iyappan,V. (2018). Innovative methods of Teaching and Learning. Journal of Applied and Advanced Research. ISSN 2519-9412.Research Gate. From: https://www.researchgate.net/publication/3250 87944_Innovative_methods_of_Teaching_and_Learning

Vijayalakshmi, M.(2019). Innovations in teaching methods. Journal of Applied Science and Computations. Volume VI, Issue I, ISSN NO: 1076-5131.ResearchGate. From: https://www.researchgate.net/publication/331149966 _Innovations_in_Teaching_Methods

Yıldııım, A., \& Șimşek, H. (2006). Nitel araştırma yöntemleri. Ankara: Seçkin Yayınları.

Yuen, A. (2004). Leading Curriculum Innovation in Primary Schools. Yew Chung College of Early Childhood Education. From: https://pdfs.semanticscholar.org/2eaf/d3bb395b434551ed5a7f3281083a3218744b.pdf 